\title{
A real-time window on 19th-century vernacular French: The Récits du français québécois d'autrefois
}

\author{
S H A N A POPLACK \\ Department of Linguistics \\ University of Ottawa \\ 422-70 Laurier Avenue East \\ Ottawa, Ontario K1N 6N5, Canada \\ spoplack@uottawa.ca \\ A N NE S T-A M A N D \\ Department of Linguistics \\ University of Toronto \\ 130 St George Street \\ Toronto, ON M5S 3H1, Canada \\ a.st.amand@utoronto.ca
}

\section{A B S T R AC T}

This article describes the construction of a corpus of spoken French with a time depth of a century and a half, the Récits du français québécois d'autrefois (RFQ). The folktales, local legends, and interviews constituting the RFQ were produced by speakers born between 1846 and 1895. They spoke the French of 19th-century rural Québec, a variety shown to be replete with the vernacular structures and inherent variability of contemporary dialects. The authors review the advantages and drawbacks associated with this type of diachronic material, and argue that, exploited judiciously, it effectively represents an earlier stage of spoken French. They show how systematic comparison of the RFQ with contemporary vernaculars can help pinpoint the existence, date, and direction of language change. (Apparent-time construct, Canadian French, corpus construction, diachronic data, language change, linguistic variability, ne deletion, real time analysis, vernacular)*

\section{N T R O D U C T I O N}

The study of linguistic change has always been hampered by the dearth of appropriate real-time data reflecting earlier stages. Most older corpora of spoken language are plagued by shallow time depth, and written texts may not be representative of oral speech, where most changes originate. The lack of reliable diachronic evidence is at least partly responsible for the widespread assumption that salient features of contemporary vernaculars are recent innovations. ${ }^{1}$ This problem is particularly relevant to varieties of Canadian French, whose distinc- 
tive and often stigmatized features are routinely ascribed to language change, whether caused by intense contact with English or by centuries of isolation from the supposedly standardizing influence of Metropolitan French.

This article describes a novel use of underutilized recordings of moribund folklore to confront these issues: the construction of a corpus of spoken French with a time depth of a century and a half, which we call the Récits du français québécois d'autrefois (RFQ). The stories, local legends, and interviews constituting the RFQ were produced by speakers born between 1846 and 1895 . They spoke the French of 19th-century rural Québec, a variety that, as we will show, is replete with the vernacular structures and inherent variability of contemporary dialects. As such, we argue that it effectively represents an earlier stage of spoken French. Systematic comparison of the RFQ with 20th-century vernaculars can help pinpoint the existence, date, and direction of language change.

The construction of this corpus and the larger research program of which it forms part fall within the tradition of historical sociolinguistics. The aim is to situate spoken vernaculars, and in particular their nonstandard features, within the context of their trajectory of development. Comparison with appropriate earlier stages enables us to determine whether these features are retentions or innovations, and if the latter, whether contact-induced or internal developments. Much effort and ingenuity has been invested in locating earlier sources of the spoken language: in plays, diaries, letters, journals, dialect surveys, metalinguistic texts, and overseas varieties (cf. Ayres-Bennett 1994, 2000, 2004; Mougeon \& Béniak 1994; Lodge 1996, 2003; Poplack 2000; Wüest 2002; Martineau \& Mougeon 2003; Dufter \& Stark 2005; Poplack et al. in preparation). Studies based upon them have yielded valuable insights into what the French spoken in the past must have been like; their authors have nonetheless been quick to caution against the facile equation of these documents with the oral usage of the time, especially for purposes of dating variant forms. Perhaps the greatest problem involves the issue of negative evidence. It is not clear how to interpret the absence of a form: because it was not in use, because the writer did not happen to use it, because it was not appropriate to the genre, or because normative conventions blocked literary usage of (nonstandard) variants that may nonetheless have proliferated in speech. Attestations can also be problematic, since French writers often employed literary conventions to represent, for comic effect, dialectal features that may not have been part of anyone's vernacular (e.g., Wüest 2002; Ayres-Bennett 2004). In addition, social information about the writers and the community is often lacking.

It is in this context, as we will show in the last section of this article, that the oral recordings constituting the RFQ are particularly valuable. But these materials must also be used with caution. Potentially detracting from their utility as an earlier stage are the possibilities that the original speakers recorded by the folklorists were not representative of 19th-century Québécois, and that their speech was not representative of the French of the time, whether because of the preva- 
lence in the recordings of ritualized expressions characteristic of performed speech genres, or superposed variants incurred by the constraints of the data elicitation procedures. An additional question, applicable to all linguistic studies carried out in real time, is whether two cohorts of speakers, born more than a century apart (1846 and 1965), may meaningfully be compared. We address each of these issues, arguing that, exploited judiciously, the RFQ is a valuable source of data on 19th-century Québec French.

In what follows, we first outline the methodological assumptions underlying this work, then describe the context in which the materials constituting the RFQ were collected, since this is what makes them especially valuable for the study of linguistic variation and change. We next detail the construction of the RFQ and the methods employed to render it linguistically useful for our purposes. Finally, we illustrate the utility of the corpus for the study of linguistic change with an analysis of one of the most widely documented features of the French language - the variable deletion, or as some would have it, REINSERTION - of the negative particle ne. Despite the prodigious amount of scholarly attention accorded this variable, and the variety of texts examined, there is remarkably little consensus on when the process of ne deletion gained ground. The oral data of the RFQ constitute a valuable adjunct to this discussion.

\section{METHODOLOG I C A L UNDERPIN NINGS}

\section{The apparent-time construct}

Efforts to reconstruct the spoken language of an earlier century inevitably rely on the assumption that speakers' vernaculars remain stable over their lifetimes. While this assumption has been widely accepted by students of language change (Labov 1966, 1994; Bailey et al. 1991; Lightfoot 1999; Anderson \& Lightfoot 2002; Bailey 2002), only recently has the kind of cross-sectional and longitudinal research necessary to test it empirically become available (G. Sankoff 2005). Such evidence consists of PANEL STUDIES, successive interviews of the same individuals at (at least) two points in time. Taken together, the results of the panel studies currently available provide strong confirmation that adult vernaculars generally remain stable over the lifetime (e.g., Labov 1994; Labov \& Auger 1998). Where change has been reported, it has almost without exception involved the phonology (e.g., Gordon et al. 2004; but see Baugh 1996), teenagers (Cukor-Avila 2000), variables involving high levels of social awareness (Labov 1994:112), and/or situations of dialect contact (Gordon et al. 2004:26162). None of these conditions is pertinent here. And it is usually the case that only some, rather than all individuals were involved (Baugh 1996; G. Sankoff et al. 2006). Older speakers in particular were found to participate only marginally in the developments taking place around them, even where the community as a whole was involved in vigorous change (Labov 1994). With regard to morphosyntax, nearly all studies have reported stability (e.g., Daveluy 1987; Lessard 
1989; Bailey et al. 1991; Cukor-Avila 2000; Bailey 2002; G. Sankoff et al. 2006). In sum, while we now know that change across the lifespan can occur, the available evidence suggests that it is the exception, not the rule. Where attested, it tends to involve especially those members of the community who engaged in long-term accommodation to a second dialect, and to be resisted by older speakers.

\section{The primacy of the vernacular}

Much of the variability of interest to sociolinguists involves nonstandard or stigmatized linguistic forms, and their trajectory over time. Because these are concentrated in the informal speech style known as the verNacular (though generally avoided in formal contexts and in writing), our comparative enterprise relies crucially on the possibility of tapping into such forms. Labov 1966, 1984 defines the vernacular as the style used unreflectingly when speakers are not monitoring their speech. In contrast to the more formal superposed variants acquired later in life and used sporadically as circumstances dictate, the rules governing linguistic variation in the vernacular, which is acquired in preadolescent years, are regular. Indeed, Labov (1984:29) characterizes the vernacular as "the most systematic data for linguistic analysis." Moreover, as the first dialect acquired, the vernacular can be expected to remain the most stable, forming the basis of historical continuity among successive language states. Thus the vernacular affords the truest indication of how far a change has progressed (Coveney 1996:278). The elicitation techniques employed by the folklorists who collected the data on which the RFQ is based were particularly conducive to the use of this speech style, as we detail in ensuing sections. The RFQ speakers acquired their vernaculars in the latter half of the 19th century; to the extent that they have remained stable, we can take them as a reflection of the speech of the time.

THE ORIGINAL COLLECTIONS

\section{The folklore tradition in French Canada}

The recordings from which we constructed the RFQ had been collected throughout French Canada in the 1940s and 1950s by the folklorists Luc Lacourcière, Carmen Roy, and their associates (Lacourcière 1946; Roy 1981), as part of an ethnographic tradition flourishing since the beginning of the century. Driven by the romantic ideals of documenting for posterity the "beauties as well as the value of bygone traditions" ${ }^{2}$ (Lacourcière \& Savard 1951:86), their goal was to create an authentic picture of French Canadian folklife, exemplified by tales, legends, songs, jokes, and assorted terminology. To achieve this goal, the folklorists turned to habitants, or country people, specifically targeting the "elite of the illiterate" (Lacourcière 1959:32), whom they considered to constitute the most direct conduit to oral tradition. Most were men over the age of 70 (Lacourcière \& Savard 1950:64), veterans of the Québec logging and fishing industries, and 
familiar with the associated lore. Women were less in demand in this connection (Lacourcière 1959:33), although fortunately for our purposes, some had been recorded.

The folklorists sought them in isolated rural areas of Québec, wherever the art of storytelling had survived (Lacourcière 1961:6). Scant information is available regarding the educational levels or occupations of the original storytellers, but as far as we can reconstruct, there was little heterogeneity among them. On the contrary, the folklorists' avowed research interests practically limited participants to insular farmers, loggers, and fishermen with little or no formal education, corresponding to the NON-MOBILE OLDER RURAL MALES (Chambers \& Trudgill 1980) coveted by traditional dialectologists for their conservative characteristics.

It is unclear just how large the original collections were, since no log is available. By Lacourcière's own tally, the Archives de Folklore collection was huge: in 1966, it contained 20,000 recordings of 6000 individuals distributed over 4000 locales across French Canada (Lacourcière 1966:226-27), collected by some 40 fieldworkers (Lacourcière 1962:254). Roy's data, concentrated in the Gaspé region of Québec, were far more modest, collected personally, and not so well documented. They made their recordings on disks or magnetic ribbon (which Lacourcière claims to have pioneered for these purposes); these were later copied onto reels.

The folklorists' field methods were exemplary (and in fact served as a model for much subsequent sociolinguistic work), consisting for the most part of participant observation achieved over "long and repeated stays in the region" (Lacourcière \& Savard 1953:99). These permitted them to build what Lacourcière called a "climate of collaboration," which he describes as "a product of trust. It implies lengthy dealings, intimate contact. It can be achieved, but only if you cast aside all prejudice, share in popular life, melt into it, so to speak, until any foreign characteristic is completely erased" (Lacourcière \& Savard 1953:99).

\section{Data elicitation}

We found little explicit information about the folklorists' data elicitation techniques. But most recordings reveal remarkably little, if any, interaction between interviewer and informant. Indeed, Lacourcière (1959:25) specifically cautions against interrupting narrations of folktales, for fear of breaking the storyteller's train of thought. Most relevant to our purposes is the express goal, enunciated by Roy (1981:284), to tap into natural speech. As we confirm in ensuing sections, the resulting rapport between interviewers and informants created conditions hospitable to spontaneous use of the vernacular, enhancing comparability with our contemporary data.

\section{NATURE OF THE DATA}

Represented in the recordings are a variety of discourse genres, including "games, expressions, sayings, proverbs, mottoes, and different statements" (Lacourcière 
1966:227). In constructing the RFQ, we focused on those that most closely resemble spontaneous conversation: contes 'tales', légendes 'legends', and interviews. By far the greatest proportion of the data (74\%) is made up of contes, narratives of a clearly fictional nature. Most of the longer contes are canonical folktales, as in (1); the shorter ones resemble jokes with a more consistent structure, as in (2).

(1) C'est pour vous dire, une bonne fois il y avait un roi qui avait sept garçons, puis c'était une chose qui était bien embêtante, son royaume ... là, celle du roi, il pouvait donner ça seulement qu'à une de ses enfants, un de ses garçons. Donc ... une journée il s'a décidé. Il dit "mes garçons," il dit, "entre vous-autres là, vous allez essayer à vous arranger d'une manière ou de l'autre. Moi," il dit, "moi, ma- ma couronne, je peux rien que la donner à un de vous-autres, puis" il dit "je veux pas être blâmé. Décidez entre vous-autres." Fait que les garçons ont regardé d'un bord puis de l'autre, bien ils ont dit, "c'est correct. On va quitter le plus jeune avec vous et puis vous lui donnerez votre couronne, nous-autres on couraillera notre chance." Ah il dit, "c'est alright." Ça fait qu'il dit, "nous-autres, ce qu'on veut, c'est un cheval, un bon cheval avec une selle, seulement." Ah il dit, "c'est correct." Il dit "choisissez." Ça fait qu'ils ont pris six des chevals, les meilleurs, puis ils ont quitté un vieux cheval noir pour le garçon qui était à la maison, donc il aurait pu s'en greyer d'autres. Fait que c'est alright, ils ont parti. Mais il dit "avant de partir," il dit, "mes garçons," il dit, "je vas quitter une tonne d'eau à la porte icitte, moi, et puis si l'eau se trouble, donc vous avez du trouble sur le chemin, puis si elle reste claire, sera bonne." $(\mathrm{RFQ} / 017: 986)^{3}$

'This is how it goes. Once upon a time there was a king who had seven boys. And there was a thing that was a real pain, his kingdom ... the king's, he could only give it to one of his children, one of his boys. So ... one day, he decided. He says, "my boys," he says, "between you, you're gonna try to work it out, one way or another. As for me," he says, "my- my crown, I can only give it to one of you guys," and he says, "I don't want to get blamed. You decide between you." So the boys looked around, well, they said, "OK. We're gonna leave the youngest with you, and you'll leave him your crown, us, we'll take our chances." Ah, he says, "that's all right." So he says, "us, what we want is a horse, a good horse with a saddle, that's all." Ah, he says, "OK." He says, "choose." So they took six of the horses, the best ones, and they left an old black horse for the boy who was at home, so he could have managed to get others. So, all right, they left . But, he says, "before leaving" he says, "my boys," he says, "I'm gonna leave a barrel of water here by the door, and if the water becomes cloudy, well, you're having trouble on the road, and if it stays clear, will be good."

(2) C'était un gars qui était dans un hôtel et puis il sortait de dans le bois, il y avait du beurre, c'était méchant, sur la table, c'était pas mangeable pas-en-toute. Il pogne le beurre dans une poignée, puis il sapre ça sur la cloison. Fait que la servante arrive, elle dit, "Qui c'est qui a fait ça?" Le gars se met à dire- il se met à regarder le beurre. "Voyons le beurre, tu es pas assez vieux pour parler, toi?" (RFQ/019:273)

'There was a guy who was in a hotel, and he had come out of the woods. There was some butter, it was bad, on the table. Couldn't eat it at all. He grabs a fistful of butter and he slaps it against the wall. So the servant comes, she says, "Who did that?" The guy starts saying - he looks at the butter. "Come on, butter, aren't you old enough to talk?"

Légendes (making up 3\% of the data) are similar in structure to contes, and also conversational in nature, but the events recounted are presented as having actually taken place (Lacourcière 1966:229). An example is given in (3). Among the criteria we used to identify a text as a légende were the use of local place names, reference to real people, and some degree of historical plausibility. 
(3) "La Corriveau" ça, c'était une femme qui avait été pris, qui avait été accusée d'avoir tué son mari, dans Saint-Tite-des-Caps icitte là, voilà astheure bien longtemps de deça. Ça fait qu'elle a passé un procès puis ils ont pas été capables de prouv-de prouver que c'était elle. Au bout d'une couple d'années elle s'est remariée en seconde noce. Au bout d'un an, ils ont trouvé encore son mari mort le long de la route avec la tête écrasée, pareil comme le premier. (RFQ/014:687)

" "La Corriveau," that was a woman who had been caught, who had been accused of having killed her husband, in Saint-Tite-des-Caps over here, a long time ago. So she went to trial and they couldn't prove - prove that it was her. A couple of years later, she remarried in a second marriage. A year later, they again found her husband dead on the side of the road, with his head smashed in, just like the first.'

As their name implies, interviews (23\% of the data) involved question-andanswer exchanges, ranging from elicitation of terminology and techniques, as in (4), to questions typical of contemporary "sociolinguistic interviews" (Labov 1984), as in (5).

(4) Est-ce qu'il y a des procédés, des techniques quelconques là, dont vous vous souvenez dans le tressage des chapeaux? (Carmen Roy/RFQ/046/052:843)

'Are there procedures, any techniques that you remember for braiding hats?'

(5) "Pouvez-vous vous- vous rappeler de vos jeux quand vous étiez petite là, aussi lointains que sont vos souvenirs? Quand vous étiez toute petite, à quoi jouiez-vous?" (Carmen Roy/RFQ/050/051:5)

'Can you- you remember your games when you were small, as far back as you can remember? When you were really little, what did you play?'

Biographical questions (place of birth, ancestry, schooling, etc.) were occasionally asked, but most interviews focused on traditional practices (e.g., fishing, boat building, log riding, agriculture, food preparation) and customs. The interviewer was often seeking a specific response, as in (6); but (fortunately for our purposes) this did not preclude answers that were longer than strictly "necessary," if not altogether tangential, as in (7).

(6) [IVer] Qu'est-ce que c'est qu'un sabourin?

[020] Le sabourin c'est un- un os de viande, quand la viande a venu rare à force, savezvous, d'en- d'en- d'en tuer. Ça a venu qu'il y en avait pas tant il y en avait quand ils avaient arrivé, bien ils prenaient un os puis ils se le passaient un à l'autre pour faire de la soupe. (RFQ/020:820)

'What's a sabourin?'

'The sabourin is a- a meat bone, when meat became scarce because, you know, too much was killed. It got so there wasn't as much as there had been when they got there. Well, they took a bone and they passed it around from one to the other to make soup.'

(7) [IVer] Quels genres de gros travaux faisiez-vous aux champs, par exemple?

[048] Ah! on coupait le grain.

[IVer] Avec-?

[048] Avec une faucille. On raclait le grain avec des râteaux, des petits râteaux ... en bois. Ensuite de ça, on arrachait les patates, dans l'automne. On semait les patates dans le printemps. On les arrachait dans l'automne. Ensuite de deça, on- mon mari pêchait à part de deça, puis c'était un gros pêcheux. C'était des côtes, puis descends la côte du plain, puis va étendre la morue, puis va laver de la morue, puis va laver du hareng, puis mets ça là, puis envoie, puis à la course tout le temps. C'est pas une vie, hein? Aujourd'hui, ils ont 
de l'agrément, aujourd'hui. Moi, je suis contente pour les femmes d' aujourd'hui. Mon Dieu! Je suis contente! Je suis contente assez qu'ils faissent pas la vie qu'on a faite, effrayant! (RFQ/048:813)

[IVer] 'What kind of work did you do in the fields, for example?'

[048] 'We cut the wheat.'

[IVer] 'With?'

[048] 'With a scythe. We raked the wheat with rakes, little wooden rakes ... Then we pulled the potatoes up, in autumn. We planted potatoes in spring. We pulled them up in autumn. Then we - my husband fished besides that, and he was some fisherman! It was hills, then down the hill to the shore, then go spread out the cod, then go wash the cod, then go wash the herring, then put this here, keep moving, on the run all the time! It's not a life, you know? Today they have some pleasure, today. Me, I'm happy for the women of today. God, am I happy! I'm so happy they don't have the life we had, horrible!'

\section{CONSTRUCTION OF THE RFQ}

The folklorists' original archives, containing some sociodemographic information (minimally name, age, and locale of recording; more rarely, occupation) for many of the participants in these projects are still available at their respective repositories, Université Laval and the Canadian Museum of Civilization. Not all of them can be linked to their associated audio tracks, and vice versa, however. The accessibility of demographic information matching the recording became a primary criterion in constructing the RFQ. Additional criteria included a date of birth predating the 20th century by as much time as possible, to enable the greatest time depth for real-time analysis. We also required that the data be sufficient in quantity and of good enough audio quality to permit reliable quantitative analysis of linguistic variability. Many of the original 40,000 recordings consist of a single song, or last only a few seconds, making them useless for the quantitative analysis of linguistic variation. Others, owing to the technology of the time, are not clear enough to allow the analyst to detect the variable presence of morphosyntactic variants, sometimes as small as a single phonetic segment. Finally, for the sake of continuity with the synchronic axis of our research (the 20th-century French instantiated in the Corpus du français parlé à Ottawa-Hull; Poplack 1989), we included only individuals from Québec. These criteria taken together explain why only a relatively small number of the original participants could be retained in the RFQ.

\section{Characteristics of the speakers}

Forty-four individuals, born between 1846 and 1895, make up the speaker sample from which the RFQ was drawn. Geographically, they are distributed across four administrative regions of Québec. All were members of the oldest generation; three-quarters of them were over 70 at the time of the interview (Table 1). Over two-thirds are men, consistent with the fact that storytelling was traditionally a male domain. Of the 11 for whom pertinent data were available, all had been laborers: fishermen, lumberjacks, or farmers. Even less is known about the women. Since both Lacourcière (Lacourcière \& Savard 1950:64) and Roy (1981:237) targeted precisely such individuals as exemplars of the art of sto- 
TABLE 1. Characteristics of RFQ speakers.

\begin{tabular}{|c|c|c|c|c|}
\hline Speaker \# & Sex & Year of birth & Age at interview & Occupation \\
\hline 001 & M & 1892 & 56 & \\
\hline 002 & M & 1888 & 67 & farmer \\
\hline 003 & M & 1857 & 89 & \\
\hline 004 & $\mathrm{~F}$ & 1860 & 88 & \\
\hline 005 & M & 1872 & 77 & logger \\
\hline 006 & M & 1895 & 60 & \\
\hline 007 & M & 1894 & 61 & \\
\hline 009 & M & 1878 & 75 & \\
\hline 011 & M & 1890 & 65 & \\
\hline 013 & M & 1881 & 73 & \\
\hline 014 & M & 1881 & 71 & logger \\
\hline 015 & M & 1882 & 73 & \\
\hline 016 & M & 1859 & 90 & \\
\hline 017 & M & $1866^{*}$ & $84^{*}$ & fisherman, farmer, railroad worker \\
\hline 018 & M & 1874 & 74 & \\
\hline 019 & M & 1888 & 68 & \\
\hline 020 & $\mathrm{~F}$ & $1846^{*}$ & $104 *$ & \\
\hline 021 & $\mathrm{~F}$ & 1881 & 74 & \\
\hline 022 & $\mathrm{~F}$ & 1881 & 74 & \\
\hline 023 & $\mathrm{~F}$ & 1876 & 79 & cook in logging camp \\
\hline 025 & $\mathrm{~F}$ & 1872 & 78 & \\
\hline 027 & $\mathrm{~F}$ & 1890 & 65 & teacher, secretary \\
\hline 028 & $\mathrm{~F}$ & 1875 & 81 & \\
\hline 032 & M & 1894 & 55 & lumberjack \\
\hline 033 & M & 1860 & 88 & \\
\hline 036 & M & 1875 & 74 & \\
\hline 037 & M & 1888 & 67 & \\
\hline 038 & M & 1864 & 86 & fisherman, shop keeper \\
\hline 039 & M & 1888 & 62 & (day) labourer \\
\hline 040 & M & 1879 & 75 & fisherman, may have been a lumberjack \\
\hline 041 & M & $1874^{*}$ & $83^{*}$ & fisherman \\
\hline 042 & M & $1869^{*}$ & $82 *$ & \\
\hline 043 & M & $1865^{*}$ & $89 *$ & fisherman \\
\hline 044 & M & 1886 & 72 & fisherman, lumberjack, healer \\
\hline 045 & $\mathrm{~F}$ & 1872 & 85 & \\
\hline 046 & M & 1886 & 72 & lumberjack \\
\hline 047 & $\mathrm{~F}$ & 1884 & 73 & \\
\hline 048 & $\mathrm{~F}$ & 1888 & 70 & (textile) factory worker \\
\hline 049 & M & $1873^{*}$ & $77 *$ & farmer \\
\hline 050 & $\mathrm{~F}$ & 1879 & 79 & \\
\hline 051 & $\mathrm{~F}$ & 1885 & 73 & \\
\hline 052 & $\mathrm{~F}$ & 1893 & 65 & \\
\hline 053 & M & $1886^{*}$ & 68 & fisherman \\
\hline 054 & M & 1872 & 78 in 1950 & fisherman, lumberjack, farmer \\
\hline
\end{tabular}

*Information reconstructed based on folklorists' notes (when available) and/or (sometimes conflicting) information given in recording. 
rytelling, we nonetheless assume that the occupational histories of the RFQ informants are representative of those of the original participants.

Explicit information about exposure to formal instruction is also lacking for most informants. Given the facts that (i) the folklorists specifically sought the untutored, and (ii) education was not yet compulsory in Québec (and thus still the province of the elite few; Corbeil 1976), we also infer that most would have had little or no access to formal schooling.

\section{The data}

Having described the informants who contributed to the RFQ, we now characterize their speech, focusing on elements that could impinge on the utility of the RFQ for the study of linguistic change in real time. We first examine the validity of the data in terms of faithfulness of the transcriptions to the original recordings. We next assess the likelihood that the speech constituting the RFQ is representative of the vernacular. We then discuss the extent to which it can be characterized as a pre-contact stage of Canadian French, by ascertaining the role of English in the speech of the informants. Finally, we examine the extent to which speakers of the past may be compared with those of the present.

\section{Validity of the transcriptions}

Much of the RFQ data had been transcribed by the folklorists and their assistants in the mid-20th century (Lacourcière \& Savard 1950). In contrast to most historical work, which of necessity must rely only on written representations of speech, the availability of the original recordings enabled us to compare systematically their transcriptions with what the speakers had actually said. The many discrepancies revealed by this exercise greatly diminish the utility of the transcriptions for linguistic analysis in general, and the study of change in particular. The excerpt in (8) illustrates this:

(8a) Original transcription

D'abord, ce qui était vital anciennement, c'était le blé pour faire $\emptyset$ la farine. Parce que la farine était produite ..., il ne venait pas de farine d'en dehors. On avait la farine du blé qu'on produisait. $\boldsymbol{E} \boldsymbol{t}$ il était important de $\boldsymbol{l} \boldsymbol{a}$ semer aussi de bonne heure que possible, parce que ça arrivait souvent l'automne qu'il gelait, $\boldsymbol{e} t$ quand il gelait, $\emptyset$ ça gaspillait la farine. (Roy 1958)

(8b) RFQ transcription

D'abord, ce qui était vital anciennement, c'était le- le- le blé pour faire $\boldsymbol{d e}$ la farine. Parce que la fe- 1- la farine était produit pour- il $\emptyset$ venait pas de fari-farine d'en dehors. On avait la farine du blé qu'on produisait. Puis il était important de $\boldsymbol{l} \boldsymbol{e}$ semer aussi de bonne heure que- que possible, parce que $\emptyset$ arrivait souvent l'automne qu'il gelait, puis quand il gelait, bien le-ça gaspillait la farine. (RFQ/046:381)

'First, what was important in the old days, was the- the- the wheat to make flour. Because the fl- th- the flour was produced for- no fl- flour came in from outside. We had the flour from the wheat we produced. And it was important to sow it as early as- as possible, because [it] often happened that it would freeze in autumn, and when it froze, well, the- that would spoil the flour.' 
Comparison of the two transcriptions shows that nearly all of the nonstandard grammatical features, italicized in (8a) and (8b) (pleonastic partitive de, lack of gender concord with participial adjectives [ produit] and pronouns [le]), omission of negative $n e$, and null subject [ $\emptyset$ arrivait $]$ ), have been edited out of the Roy version. Instances of the vernacular puis 'and' have been replaced by standard et. Precisely such features are key to the study of the evolution of spoken French; by standardizing them, the original transcription actually obscures their trajectory of variation and change. Elsewhere the transcribers make ample use of eye dialect (e.g., the conventionalized apostrophes for deleted material: $i$ ' for $i l$, v'nu for venu, etc.), while at the same time missing much of the important variability. Since their stated goal was to capture natural, authentic speech, we assume that the folklorists instructed the transcribers to render it as faithfully as possible. Although the original recordings were available for verification, these were not linguists, so the discrepancies are not particularly surprising. They do, however, raise (yet again) the question of the relationship between the representations of speech commonly appealed to in reconstructing the spoken French of the past (e.g., those of Molière and Hérouard) and the actual speech of the times.

The University of Ottawa Sociolinguistics Laboratory research team spent over a year and a half retranscribing, correcting, standardizing and recorrecting the data, taking the original recordings rather than the transcriptions as a point of departure. Following the model of previously constructed large-scale speech corpora (Poplack 1989; Poplack \& Tagliamonte 1991), in building the RFQ, we employed a strict protocol that enhances searchability while retaining maximal linguistic detail. The resulting corpus, totaling 510,307 words, is now computerized and fully machine-accessible.

\section{The RFQ as an instantiation of the vernacular}

Since the RFQ is mainly made up of folktales and legends, the language of the kings, princes, princesses, ogres, giants, and other characters peopling them could reasonably be expected to contain many ritualized and archaic forms (cf. the néo-contes studied by Carruthers 2003). Well-known examples of such forms include il fut un temps 'there was a time [once upon a time]', which makes formulaic use of the now defunct passé simple, and n'eût été que 'had it not been for', constructed with the extinct imperfect of the subjunctive, and the virtual absence of the negative marker ne. A preponderance of such forms would vitiate the RFQ both as evidence of the vernacular and as evidence of an earlier stage, since we would not know for sure whether the forms were in productive use or recurring relics. Systematic examination of the corpus, however, confirms that the speech represented therein displays all the vernacular structures and inherent variability typical of contemporary varieties, with few, if any, differences due to genre (although this factor will be tested systematically in future quantitative studies). Even where the most formal registers could be expected, as in the discourse of kings, as in example (1), princes (9a), princesses (9b), and God him- 
self (9c), typical nonstandard features (italicized in the examples) are used, consistent with ordinary usage.

(9a) Prince: "Ah," il dit, "princesse, pour le dernier matin que je suis icitte, c'est pas possible que je [Ø] tuse pas un gibier de même à mon père." (RFQ/018:467)

“"Ah” he says, Princess, on the last morning I'm here, there's no way that I won't [ $\left.\emptyset_{n e}\right]$ kill one of those game animals for my father.'"

(9b) Princess: " $[\varnothing]$ m'en vas étouffer! Aye! Je me meurs! Certain, $[\varnothing]$ me meurs!... M'a mourir! M'a mourir!" (RFQ/018:407)

'Gonna suffocate! I'm dying! For sure, am dying! ... I'm gonna die! I'm gonna die!'

(9c) Dieu: "Tu veux-TU me suivre, sacreur?" .. tu- tu vas me promettre de $[\varnothing]$ plus sacrer." (RFQ/023:2282)

'God: "You want-TU to follow me, Blasphemer? ... "you- you have to promise me [Ø ne] not to swear anymore.'"

These few examples alone include, in addition to the many nonstandard lexical items, vernacular variants of morphosyntactic variables such as plural marking (1), subjunctive morphology (1), preposition usage (9a), future marking (9b), and question formation (9c), as well as auxiliary avoir for être (1), null subject $(1,9 \mathrm{~b})$, and negative ne deletion $(1,9 \mathrm{c})$, among others. More can be found in the other citations reproduced here. This is a veritable windfall, especially in comparison with the paucity of such examples in the literary and semiliterary representations of the spoken French of the past, where the syntax is almost completely standardized (Ayres-Bennett 2000:341).

Even when exactly the same folktale is recounted, a situation that could be expected to lead to ritualization, variability persists. This is illustrated in (10), which reproduces ostensibly the same quotation from three renditions of the tale variously referred to as Deux conseils and Trois conseils 'Two/Three pieces of advice'.

(10a) "Bien," il dit, “je m'en vas te dire de toujours mettre (INF) ta colère au lendemain," il dit ça. (RFQ/001:445)

"'Well," he says, "I'm going to tell you to always put your anger off until the next day," he says that.'

(10b) "Le deuxième conseil," il dit, "pour le reste de tes jours que tu aurais à vivre encore, mets (IMP) toujours ta colère au lendemain." (RFQ/032:170)

" "The second piece of advice," he says, "for the rest of your days that you still have to live, always put your anger off until the next day." "

(10c) "Bien, tu mettras (FUT) toujours ta colère au lendemain." (RFQ/033:1491)

“"Well, you'll always put your anger off until the next day.",

The innkeeper in $(10 \mathrm{a}-\mathrm{c})$ is made to use three distinct variants of the imperative variable: the infinitive (mettre ta colère), the imperative (mets ta colère) and the inflected future (tu mettras ta colère). The identification of such cases of inherent variability is at the core of our comparative endeavor in the establishment of linguistic change (cf. Poplack \& Tagliamonte 2001). In contrast to 
previous uses made of these materials (e.g., Poirier 1973; Juneau 1976; DrapeauForzani 1977), we employ them to compare the structure of PRIOR VARIABILITY with contemporary counterparts. On this basis we determine the existence and direction of change, as well as the linguistic and extralinguistic constraints operating upon it.

\section{The RFQ as a pre-contact stage of Québec French}

We noted earlier that one of the driving forces behind the construction of the RFQ was to document scientifically the role of language contact (as opposed to internal evolution) in the development of Québec French. Many of its more salient nonstandard features are routinely ascribed to its contact with English since the British conquest of Canada (1760). As we have described elsewhere (Poplack \& Meechan 1998; Poplack \& Tagliamonte 2001; Poplack et al. 2006), scientific proof of contact-induced change can come only from systematic comparison of the presumed contact variety with a pre-contact stage of the language. Given the insularity of the RFQ speakers described above, their French could be inferred to represent just such a pre-contact stage, providing it has resisted change attributable to contact with English.

The paucity of sociodemographic information regarding the RFQ informants extends to their knowledge of and exposure to English. Only seven explicitly reported any knowledge of the language. Nonetheless, it is unlikely that they could have escaped contact with English entirely. Anglophones were not uncommon in Québec lumber camps of the 19th and 20th centuries (Pomerleau 1997:25). French Canadians also often logged in English-speaking areas (Pomerleau 1997:27), though only one RFQ informant reported having lived in one for any length of time. From the anecdotes of the informants, we infer that anglophones were also a non-negligible presence on the fishing boats. Nonetheless, a number of narratives confirm that working knowledge of English was unusual enough to be a reportable commodity.

The potential for language contact was there, but what impact, if any, did it have on 19th-century Québec French? Social factors are not reliable predictors; the effects of contact can be assessed only from traces left in the language. The most obvious are lexical, as represented by borrowing and code-switching, thought by some (Thomason 2001; Backus 2005) to be necessary precursors to structural change. Analysis of wordlists and concordances generated for the RFQ reveals that at $0.2 \%$ of the total verbal output, borrowing from English is at best a minor phenomenon, largely restricted to a few individuals, and often involving terminology elicited by the interviewers (Poplack \& St-Amand forthcoming). Code-switching involving multiword fragments of English is even rarer. Only 69 tokens were detected in the half-million-word RFQ corpus, most uttered by three individuals, each in the context of a single long anecdote.

Thus, contrary to the received wisdom that only a few decades after the British conquest Canadian French would already have been teeming with anglic- 
isms, the inroads English had made into 19th-century French a full century and more later were few in number, superficial in nature, and sporadic rather than established. ${ }^{4}$ We conclude that contact with English had not altered the grammatical structure of the French recorded in the RFQ. As such, it qualifies as a viable benchmark against which contemporary varieties may be assessed.

\section{Comparing speaker cohorts}

A final issue with respect to representativeness applies to all real-time trend studies involving speakers, especially those featuring substantial time depth. Ideally, comparison groups would be matched on all relevant socioeconomic characteristics, but the more time that has elapsed since the original survey, the more different the populations are likely to be (Bailey 2002; Gordon et al. 2004). Thus the RFQ speakers - loggers, fishermen and other country people - appear to be the antithesis of the urban Ottawa-Hull residents who constitute the 20th-century comparison group. Many of the discrepancies between speaker cohorts are direct reflections of dramatic societal changes over the past century and a half. When the RFQ speakers were growing up, the Québécois economy was predominantly agricultural, and the working classes were made up of the rural population. As late as Confederation (1867), the urban population was estimated at only 15\% (Corbeil 1976). Moreover, in 1842 the rate of school attendance was under 5\% (Corbeil 1976:15). In this context, the individuals targeted by the folklorists were in fact representative of their contemporaries, just as those making up the 20th-century sample (Poplack 1989) are of theirs. Only in the early 20th century did a profound social upheaval take place, with many rural individuals migrating to the cities, where they eventually entered the urban working class. The urban population of the 19th century was statistically equivalent to the rural population today - negligible. In this context, the proper descendants of the rural Québécois of the 19th century are in fact the urban working classes of today. Indeed, even had we been able to manipulate the sampling procedure of the earlier period, the time frame, in conjunction with the social upheaval, would have precluded establishing two speaker samples simultaneously representative of their time AND comparable to each other.

This is not to deny the obvious differences in education, occupation, and general sophistication. These could be invoked to explain DIFFERENCES between the 19th-century French instantiated in the RFQ and contemporary varieties. According to Meillet 1921 (cited in Labov 1994), the only variable explanatory of linguistic change is social change. Social change does not ENTAIL linguistic change, however. And in fact, results of a large number of comparative studies undertaken in conjunction with this project converge in showing remarkable parallels across data sets. Virtually all of the morphosyntactic variables documented in contemporary varieties were not only already present in the RFQ, but more important, they were largely constrained in the same way. Examples include variable choice of indicative mood in subjunctive-selecting contexts (Poplack 1992, 
1997; Poplack \& St-Amand 2002; St-Amand 2002), substitution of the conditional for the standard imperfect in protases of hypothetical si-complexes (LeBlanc 1999, 2002; LeBlanc \& Poplack 1999, 2003), selection of the avoir auxiliary with so-called être verbs (Willis 2000), restriction of the synthetic future to negative contexts (Poplack \& Turpin 1999, Poplack \& Dion 2004), variable deletion of complementizer que (Dion 2003, 2006; Dion \& Torres-Cacoullos 2003), variation in gender marking (Klapka 2002), variation in pronoun usage (Blondeau 2002, 2003, 2004), null subjects (Leroux \& Jarmasz 2006), and variable question formation (Elsig \& Poplack 2006), among others. The studies of Klapka, Dion and St-Amand additionally show the RFQ speakers to be more conservative vis-à-vis ongoing changes than even the oldest of their 20th-century counterparts, and some variants now extinct had not yet become so (e.g., the passé simple; Leroux 2004). All of this is consistent with the inference that their language represents an earlier stage.

To contextualize such stability, recall that the RFQ speakers were insular individuals with relatively little contact with other dialects and thus little impetus to shift toward them; their lack of formal education minimized the superposition of formal variants; morphosyntactic features - the focus of our project - appear to be more stable than lexicon or phonology; and perhaps most important, the vernacular speech the folklorists elicited would seem to be more resistant to change across the lifespan than other styles acquired later in life. The particular political and cultural role of the vernacular in francophone Québec no doubt also played a role. Since the second half of the 20th century, the speech variety of the working and rural classes (once derogatorily termed joual) has come to be emblematic of Québecois identity. The cultural renaissance associated with the sovereignty movement, in conjunction with the increased upward mobility of French Canadians, resulted in the (covert) validation of the vernacular as the language of the Québécois, as distinct from Metropolitan French or other foreign, superposed varieties. This may explain why virtually all of the nonstandard features attested in the RFQ remain equally characteristic of contemporary vernaculars.

CONTRIBUTION OF THE RFQ TO THE STUDY OF CHANGE

Lacourcière (1946:492) was himself quite eloquent about the value of the recordings for specifically linguistic study, not only as a repository of traditional dialectal variants, but more important from our perspective, as historical evidence of an earlier stage of Québec French:

While our religious, educational, political, and professional institutions have evolved, and inevitably their language with them, the speech of our country folk has remained, like the peasantry itself, more similar to what it was. (Lacourcière 1946:492; translation ours) 
However, with few exceptions (La Follette 1969; Poirier 1973, 1998; Juneau 1976; Drapeau-Forzani 1977), neither he nor anyone else to our knowledge has systematically exploited these materials for the purpose of linguistic analysis, as we do in this research program. Below, we illustrate one way in which the RFQ may be exploited, and in so doing, assess the utility of the RFQ for the real-time study of linguistic change.

\section{A case study: The evolution of "negative" ne as a marker of formality}

In the remainder of this article, we illustrate the utility of the RFQ for the study of linguistic change with an analysis of one of the most widely documented features of the French language - the variable deletion, or as some would have it, REINSERTION - of the negative particle $n e$, as in (11).

(11) Parce qu'en ce temps là l'argent $\boldsymbol{n}$ 'était pas commune, savez-vous, elle $\emptyset$ était pas parlée beaucoup. (RFQ/020:288)

'Because in those days money wasn't common, you know, it wasn't [ $\left.\varnothing_{n e}\right]$ talked about much.'

$\mathrm{Ne}$ is prescribed in virtually all negative contexts, but in the spoken language, especially in Canada, it is almost always absent. It is generally agreed that ne no longer plays a (linguistic) role in the French negation system, yet, as in (11) and Appendix A, a few tenacious tokens continue to surface (cf. also G. Sankoff \& Vincent 1977).

A good deal of scholarly attention has focused on determining the recency of the phenomenon of ne deletion (see, e.g., discussions in Ayres-Bennett 1994; Ashby 2001; Martineau \& Mougeon 2003; Dufter \& Stark 2005). But the time frame of this change remains contentious, with some scholars (Posner 1985; Blanche-Benveniste \& Jeanjean 1986; Dufter \& Stark 2005) maintaining that $n e$ deletion was already prevalent in popular French in the 17 th century, and others (Pohl 1975; Ashby 1981; Martineau \& Mougeon 2003) arguing that the rise of this phenomenon is far more recent. Ayres-Bennett (1994:81) attributes the controversy to the difficulty of locating "reliable information on the spoken usage of the past," while Martineau \& Mougeon 2003 invoke the lack of systematic corpusbased diachronic research. They attempt to remedy the situation with an analysis of the sociolinguistic trajectory of ne over several hundred years, based on a variety of written sources "selected to represent nonstandard spoken French" (2003:125).

As a rare and precious source of diachronic speech, the RFQ can help us date the disappearance of $n e$, and through systematic quantitative comparison with contemporary materials, its current function, if any. In addition, because Martineau \& Mougeon's 19th-century Québec French texts cover much of the period during which the RFQ speakers acquired their vernaculars (1842-1899), comparison will help establish the reliability of written representations of speech, and hence the degree of accuracy they afford in dating linguistic change. 
TABLE 2. Rates of ne in 19th- and 20th-century French.

\begin{tabular}{lcrc}
\hline \hline & $\begin{array}{c}\text { N negative } \\
\text { utterances }\end{array}$ & $\begin{array}{c}\mathrm{N} \\
n e\end{array}$ & $\begin{array}{c}\% \\
n e\end{array}$ \\
\hline $19^{\text {th }}$ century (RFQ) & 9438 & 12 & $0.1 \%$ \\
$20^{\text {th }}$ century (Ottawa-Hull) & 61316 & 152 & $0.2 \%$ \\
\hline \hline
\end{tabular}

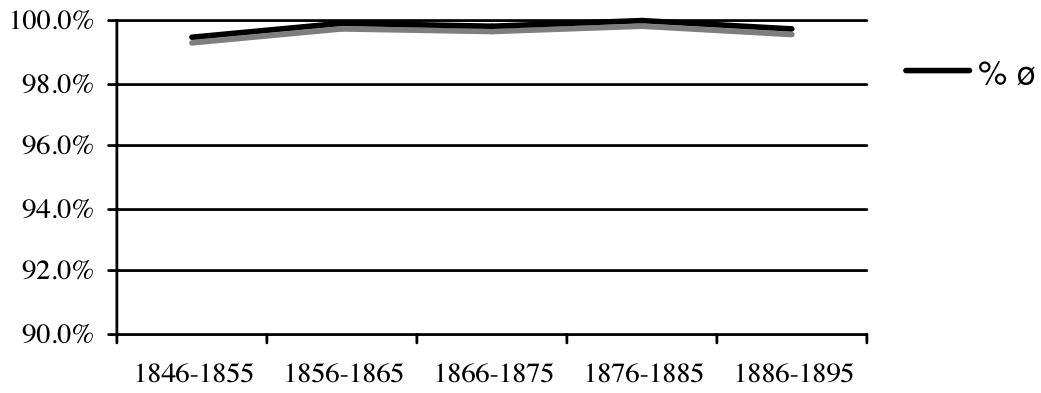

FIGURE 1: Progression of ne deletion in the 19th century.

We make use of the variationist method (Labov 1984; D. Sankoff 1988a, 1988b; Poplack 1993; Poplack \& Tagliamonte 2001), and in particular the PRINCIPLE OF ACCOUNTABILITY, which requires that we consider not only all the cases in which ne occurred, but also all those in which it could have occurred but did not. This involved identifying and extracting every context featuring a postverbal mark of negation - pas, plus, rien (que), jamais, point, aucun(e), personne, guère - noting those in which ne had actually surfaced, as well as any other pertinent contextual information (e.g., type of negative item, subject, verbal complement). Access to large quantities of natural speech, coupled with the efficiency of computerized data manipulation, makes it possible to examine vastly more negative contexts than have ever been studied before in this connection: 9438 in the RFQ and 61,316 in contemporary French (of the Ottawa-Hull French Corpus). This enhances the reliability of our results. We compared their behavior across data sets in terms of both rate of occurrence of $n e$ and conditioning of its selection.

The results in Table 2 and Figure 1 confirm earlier observations that $n e$ is virtually nonexistent in contemporary Canadian French (e.g., G. Sankoff \& Vincent 1980); in the Ottawa-Hull region it is absent from $99.8 \%$ of all negative contexts (basically the same rate attested for Montreal). They also show that this was already the case by the mid-19th century, and thus no change has taken place with regard to rate. 
Since these sporadic uses of ne could not have signaled negation (if only because they were hardly ever there), what was their function, if any? To answer this question, we systematically searched the RFQ corpus to ascertain whether any of the conditioning factors cited in the literature were operative, such as subject type (Pohl 1975; Coveney 1996; Martineau \& Mougeon 2003), type of verbal complement (Martineau \& Mougeon 2003), type of postverbal negator (Coveney 1996), lexical identity of the verb (Pohl 1968; Ashby 1981; Moreau 1986; Coveney 1996), and emphasis or repair (Grevisse 1986). Inspection of the 12 negative utterances featuring ne (Appendix A) shows no particular association with any of these (or other) factors..$^{5}$ They are simply garden-variety negative sentences. Such seemingly random variant selection is consistent with linguistic obsolescence. If this was already the situation in the 19th century, why and how has ne persisted until now, and even more puzzling, at the same minuscule rate?

Comparison of the 152 cases $(0.2 \%)$ where $n e$ surfaced in 20th-century French (Table 3) reveals that a disproportionate number of them - 83\% - occurs in topics associated with formal speech styles: religion (as in 12a), language (12b), education (12c), and moralizing or "soapbox speech" (12d) more generally, showing exactly the pattern reported by G. Sankoff \& Vincent 1977, 1980 for Montreal French c. 1971.

(12a) Le Bon Dieu a dit "tu $\boldsymbol{n} \boldsymbol{e}$ tueras point." $(\mathrm{OH} / 107: 1636)$

"The Good Lord has said, "Thou shalt not kill.",

(12b) On a vieilli en faisant le choix de bien parler notre français ou de $\boldsymbol{n} \boldsymbol{e}$ pas bien le parler. $(\mathrm{OH} / 115: 1217)$

'We grew up making the choice between speaking our French well, or not speaking it well.'

(12c) Puis si tu parlais, il te donnait un copiage, il te donnait deux feuilles: "je ne dois pas parler en classe." (OH/025:1812)

"And if you talked, he gave you lines, he gave you two pages: "I must not talk in class.",

(12d) Je $\emptyset$ pense pas que ce soit bon pour le jeune lui-même parce que la moindre petite épreuve, étant donné qu' il a tout eu, alors il ne peut pas l' accepter. (OH/106:323)

'I don't think $\left[\varnothing_{n e}\right]$ that it is good for the young man himself, because the slightest little hardship, since he has had everything, well, he won't be able to accept it.'

These four topics represent fewer than one-quarter of the subjects discussed in the Ottawa-Hull French corpus, but a disproportionate number of expressed $n e$ is concentrated here. Another $6 \%$ are in frozen expressions or quotations, as in (13).

(13) Si vous désirez plus de renseignements, $\boldsymbol{n}$ ' hésitez pas à téléphoner. (OH/119:1941)

'If you wish more information, do not hesitate to phone.'

This means that a full $89 \%$ of the already vanishingly small $(0.2 \%)$ number of $n e$ are now reserved for hyperstylistic (Bell 1984), specialized, or formulaic uses. 
TABLE 3. Distribution of ne according to topic: 20th century.

\begin{tabular}{lrr}
\hline \hline Topic & $\mathrm{N} n e$ & $\%$ \\
\hline Religion & 53 & $35 \%$ \\
Soap-box speech & 40 & $26 \%$ \\
Language & 26 & $17 \%$ \\
Education & 7 & $5 \%$ \\
Frozen expressions & 5 & $3 \%$ \\
Quotations & 4 & $3 \%$ \\
Total "specialized" $\boldsymbol{n e}$ & $\mathbf{1 3 5}$ & $\mathbf{8 9 \%}$ \\
Other $n e$ & 17 & $11 \%$ \\
TOTAL & 152 & $100 \%$ \\
\hline \hline
\end{tabular}

This association was not apparent in the past, raising the question of whether such functional expansion (undoubtedly abetted by loss of the role of negator presumably once played by $n e$ ) represents a recent change. To find out, we again compare with the 19th-century French represented by the RFQ. We already noted that there was nothing "special" about the sentences containing ne (Appen$\operatorname{dix} \mathrm{A})$. To be sure, we detect a fixed expression in (i), a quasi-citation of a king (g), and a sentence addressed to a prince (h). The principle of accountability, however, coupled with the preponderance of contes in the RFQ, means that there are thousands of negative utterances addressed to, or uttered by, kings, princes, and other lofty personages, which are all lacking ne. (Four of them appear in examples 1,9a and 9c.) This is the basis for our observation that $n e$ is certainly not CONCENTRATED in these contexts, as we have seen it to be in the 20th century. One possible explanation, in view of the folklorists' criteria for data collection, is that the formal topics so favorable to ne in contemporary speech may not even have been discussed in the RFQ. To rule out this possibility, we must control for the distribution not of $n e$, but of TOPICs in each corpus.

Table 4, which compares the distribution of topics in a subsample of 19thand 20th-century French, shows, predictably, that neither language nor education was in fact discussed in the RFQ, so these contexts obviously could not display an association with ne. But both corpora contain soapbox speech and discussions of religion. It is thus particularly noteworthy that not a single instance of ne occurred in the first context in the 19th century, whereas in the 20th a full $26 \%$ are concentrated here. The topic of religion is even more revealing, because it represents the same proportion (3.6-3.8\%) of topics discussed in both corpora. If no change had occurred, the null hypothesis is that discussions involving religion should display the same proportion of ne tokens at both time periods. Instead, the contemporary data feature $35 \%$ ne usage, compared to a rate of only $8 \%$ (i.e. a single instance, reproduced in ex. 14) in the 19th century. 
TABLE 4. Distribution of topics by century.

\begin{tabular}{lcc|cccc|c}
\hline \hline & Language & Education & \multicolumn{3}{|c|}{ Soap-box } & Religion & Other \\
\hline & $\%$ & $\%$ & $\%$ & $\%$ of all $n e$ & $\%$ & $\%$ of all $n e$ & $\%$ \\
\hline $\begin{array}{l}19^{\text {th }} \text { century } \\
(\text { RFQ })\end{array}$ & 0.2 & 0.5 & 1.2 & 0 & 3.6 & 8 & 94.5 \\
$\begin{array}{c}20^{\text {th }} \text { century } \\
(\text { Ottawa-Hull })\end{array}$ & 11.1 & 5.5 & 3.7 & 26 & 3.8 & 35 & 76 \\
\hline \hline
\end{tabular}

This is a statistically significant increase $(\mathrm{p}<.05$ by Fisher's Exact Test, which takes into account the small number of $n e$ tokens in the RFQ).

(14) Et puis, le curé du temps, bien $\mathrm{n}-\boldsymbol{n} \boldsymbol{e}$ voulant pas se- se soumettre, ils ont été ni plus ni moins excommuniés, hein? (RFQ/027:334)

'And since the curé at the time didn't want to give in, they were simply excommunicated.'

The current association of ne with formal speech suggested by Tables 3 and 4 is bolstered by its concomitant concentration among upper-middle-class speakers, displayed in Table 5. This of course enhances its connotations of prestige, in addition to those of careful speech.

Our comparison of ne usage in 19th- and 20th-century Québec French leads us to conclude that there has in fact been a recent change in ne usage, but, contrary to claims based on written representations of speech, it does not involve a decrease in RATE. Rather, the change is FUNCTIONAL: $n e$ has become a sociostylistic marker of formality. Interestingly, this change seems to have been driven by women, traditionally the exponents of standard speech. Despite the exceedingly sparse data on ne overall, it is worth noting that though women represented only one-third of the 19th-century sample, more than half of all ne were uttered by them. This may well have set the stage for the contemporary specialization of $n e$ as a prestige marker of careful speech, and by extension, its association with upper classes in formal styles.

We cannot reconstruct all the events that led to the current situation, but the introduction in Québec of compulsory education in the second half of the 20th century surely played a role. From that time on, anyone with formal instruction in French would have learned that every postverbal negator (pas, jamais, etc.) requires a preverbal ne. This knowledge has had no effect on the spoken language, since, as we have seen, the RATE of ne usage has not changed at all since 1846 (cf. Poplack \& Malvar 2007 for a similar situation in Brazilian Portuguese). But the idea persisted that to speak really well, a few ne should be introduced. This is what explains the current preponderance of ne specifically in discourse requiring elevated speech styles. It also explains why, in a discourse 
TABLE 5. Distribution of ne according to socioeconomic class: 20th century.

\begin{tabular}{lrc}
\hline \hline $\begin{array}{l}\text { Socioeconomic class/ } \\
\text { Neighbourhood }\end{array}$ & N $n e$ & $\%$ \\
\hline UMC Mont-Bleu & 46 & $30 \%$ \\
UWC WestEnd & 35 & $23 \%$ \\
WC Vanier & 25 & $16 \%$ \\
$\quad$ Basse-Ville & 25 & $16 \%$ \\
$\quad$ Vieux-Hull & 21 & $14 \%$ \\
TOTAL & 152 & $99 \% *$ \\
\hline \hline
\end{tabular}

*Due to rounding.

featuring several negative contexts, only one will feature $n e$. Its salience is such that one is more than sufficient to convey the desired sociostylistic information. We can thus confirm that even a moribund morpheme with no apparent linguistic work, like 19th-century ne, may resist erosion, providing it retains a discourse function.

Our real-time comparison of two distinct stages of the spoken language also brings important new evidence to bear on the evolution of Québec French, and specifically on Martineau \& Mougeon's claim that "the trend to delete ne rose during the 19th century in Québec French" (Martineau \& Mougeon 2003:134). Focusing on their corpus of 19th-century texts, we may confront this claim with actual spoken data of the same period, as instantiated in the RFQ. Martineau \& Mougeon 2003 examined 258 negative sentences found in diary entries written between 1842 and 1845, and a further 110 negative sentences culled from plays written between 1856 and 1899. In reviewing their evidence, we point out that the authors took pains to distinguish the social provenience of both diarist/ characters (all of roughly the same lower status as the RFQ speakers), and the texts they infer to be representative of their speech (which, like the RFQ, also contain many other nonstandard features, according to them). Rates of ne omission are reported as $40 \%$ in the former, and $57 \%$ in the latter. Fully cognizant of the caveats involved in equating literary texts with actual speech $(2003: 126)$, the authors are admirably cautious about identifying these rates as accurate measurements of ne frequency (2003:136). On the basis of this evidence, they nonetheless conclude that "the trend to delete ne rose during the 19th century in Québec French," further citing evidence of social stratification and style shifting (Martineau \& Mougeon 2003:135). In contrast, our analysis of RFQ data - representing approximately the same period and involving individuals of the same social strata and their informal colloquial speech - reveals, at a rate of $99.9 \%$ deletion, a change that has virtually gone to completion. Only 9 of the 44 RFQ speakers 
used ne at all, most of them no more than once. We detect no evidence of style, topic, or genre shifting, nor any sign of social stratification: Even the single former schoolteacher in the sample uses the same (infinitesimal) amount of $n e$ as the eight other ne users in the RFQ sample. In order for the process of ne deletion to have reached near completion by the mid-19th century (barring any as yet undocumented catastrophic event), its rise must have substantially PRE-DATED the 1800s.

\section{I S C U S S I O N}

As a contribution to ongoing efforts to reconstruct the history of spoken French, in this article we detailed a novel use of underexploited folklore recordings. Judicious selection of these materials, retaining speakers born as far in the past as possible and speech most closely resembling conversation, enabled us to build the corpus we have called the Récits du français québécois d'autrefois. Despite the fact that most of the data occur in folktales and legends, which could be expected to contain stylized language, systematic examination showed the vernacular structures and inherent variability characteristic of unreflecting speech. Analysis further revealed that influence from English was practically nonexistent. Invoking the apparent-time construct, and bolstered by the insularity of the participants and the relative stability of the vernacular, as well as of the morphosyntactic features that are our primary focus, we inferred that the RFQ speakers were unlikely to have altered their morphology and syntax appreciably over their lifespans. On this basis, we argued that these materials reflect the vernacular speech of 19th-century Québec, a variety which for all intents and purposes serves as a pre-contact benchmark with respect to contemporary varieties.

As with all diachronic sources, which survive by chance rather than by design (Labov 1994), these materials are not without drawbacks. Chief among them is the question of comparability of the individuals targeted by the folklorists and the urban population of the late 20th century. Such differences are unavoidable whenever a population is re-interviewed (Bailey 2002), a fortiori where major social changes have occurred. But social change need not result in linguistic change. And as our comparative research to date has uncovered remarkably few qualitative changes between older and contemporary speech, these concerns are not pertinent here. We suggested that this stability may be attributed, at least in part, to the validation and adoption of the vernacular as a symbol of Québecois identity.

In any event, we submit that the advantages of these materials far outweigh their drawbacks. Most notable among them is the fact that these data are true EXEMPLARS of speech rather than representations thereof. Access to both original transcriptions and recordings afforded a rare opportunity to compare the two, thereby offering a check on the depictions of speech on which historical linguists have heretofore relied. The folklorists put a premium on natural speech 
and developed specific methods to elicit it; they would presumably have instructed their transcribers not to obscure it. Yet even under circumstances this propitious to faithful rendering of the data, the discrepancies between transcriptions and recordings were so great as to invalidate the former as a reliable source of data on the spoken language. As with many other historical portrayals of speech, here too the "spoken flavor" is almost always conveyed through phonetic and lexical features (Ayres-Bennett 2000; also Wüest 2002). As a result, vernacular morphosyntactic features were grossly underrepresented. Perhaps normative injunctions on the use of $n e$ encouraged its retention in even semiliterate and/or informal writing well after it disappeared from speech. ${ }^{6}$ Or this may be just another instance of written representations lagging far behind oral usage (e.g., Poplack \& Malvar 2007). Whatever the reason, our findings add a cautionary note to those already expressed by scholars attempting to reconstruct spoken vernaculars from written texts. We conclude that there is no substitute for realtime data in the diachronic study of linguistic change.

\section{APPENDIX A $: n e$ UTTERANCES IN RFQ}

(a) Le... le- le géant $\boldsymbol{n} \boldsymbol{e}$ fait pas de cas. (RFQ/004:2255)

'The... the- the giant doesn't worry about it.'

(b) Il cherche un secousse, mais il ne trouve rien. (RFQ/018:1067)

'He looks for a while, but he doesn't find anything.'

(c) Voilà cinq minutes qui passent, Ti-Jean a les bras ouverts pour ne pas toucher à la princesse. (RFQ/018:2781)

'Five minutes go by, and Ti-Jean has his arms open so as not to touch the princess.'

(d) Parce qu'en ce temps là l'argent $\boldsymbol{n}$ 'était pas commune, savez-vous, elle $\emptyset$ était pas parlée beaucoup. (RFQ/020:288)

'Because in those days money wasn't common, you know, it wasn't [ $\left.\varnothing_{n e}\right]$ talked about much.'

(e) Et puis, le curé du temps, bien n- ne voulant pas se- se soumettre, ils ont été ni plus, ni moins excommuniés, hein? (RFQ/027:335)

'And since the curé at the time didn't want to give in, they were simply excommunicated.'

(f) Non, je $\boldsymbol{n} \boldsymbol{e}$ crois pas, mais seulement que, je le tiens de ma mère, elle, bien... (RFQ/ 027:402)

'No, I don't believe so, it's just that I got it from my mother, she, well...'

(g) "Bien," elle dit, "peut-être," elle dit, "que le roi ne dira rien." (RFQ/036:3957)

“"Well," she says, "maybe," she says, "the king won't say anything.",

(h) "Bien," elle dit, "monsieur, monsieur le prince," elle dit, "on ne refusera pas." (RFQ/ 038:1666)

"“Well," she says, "your highness, your highness the prince," she says, "we will not refuse.",

(i) On dit que pierre qui mousse- qui roule, ne ramasse pas de mousse. (RFQ/045:61)

'They say that a moss- rolling stone gathers no moss.' 
(j) Je $\boldsymbol{n} \boldsymbol{e}$ crois pas. (RFQ/046:864)

'I don't think so.'

(k) Ce- ce n'était pas une camisole. (RFQ/052:300)

'It- it was not a camisole.'

(1) Les tapis de plancher ce $n$ 'était pas tissé, c'était tressé. (RFQ/052:1529)

'Floor rugs were not woven, they were braided.'

\section{NOTES}

* The research on which this article is based was generously funded by the Social Science and Humanities Research Council of Canada and a Killam Research Fellowship to Poplack. We are very grateful to friends and colleagues Diane Vincent and Claude Poirier of Université Laval, and especially to archivist M. Jean Coulombe and the staff at the Archives of Folklore there. Without their precious collaboration, this project could not have come to fruition. Carmen LeBlanc and Lauren Willis collected much of the data for the RFQ, and, along with Lyne Klapka and Dawn Harvie, also participated in corpus transcription and correction. Our thanks to them and the other members of the research team at the Sociolinguistics Laboratory, University of Ottawa, for their painstaking work.

${ }^{1}$ In fact, the controversy provoked by this issue among German Romanists in the 1970s and 1980s gave impetus to the continuing search for sources of the spoken language of the past (see Ayres-Bennett 2000, 2004 for discussion).

2 All translations are ours.

${ }^{3}$ Codes in parentheses identify the corpus, speaker, and line number of the utterance in the RFQ. Transcriptions are verbatim reproductions of the recordings, transcribed in accordance with the protocol described in Poplack \& St-Amand forthcoming.

${ }^{4}$ An important proof is the absence of the overwhelming majority of 19th-century English-origin incorporations from contemporary varieties.

5 The fact that most of them co-occur with pas as opposed to other negators, and fewest with full NP subjects as opposed to pronouns, simply reflects distributional tendencies for these items in the corpus as a whole, and should not be taken as evidence of the association of the deleted variant with specific contexts (cf. Martineau \& Mougeon 2003).

${ }^{6}$ A parallel though inverse situation has been documented with respect to the highly salient and stigmatized African American Vernacular English ain't: even in "semiliterate" letters that were not only replete with other nonstandard features but also showed striking parallels with speech in conditioning of variant selection (Van Herk \& Poplack 2003), ain't was conspicuously absent (Van Herk 1999).

\section{REFER EN C ES}

Anderson, Steven R., \& Lightfoot, David W. (2002). The language organ: Linguistics as cognitive physiology. Cambridge: Cambridge University Press.

Ashby, William (1981). The loss of the negative particle ne in French: A syntactic change in progress. Language 57:674-87.

(2001). Un nouveau regard sur la chute du ne en français parlé tourangeau: S'agit-il d'un changement en cours? French Language Studies 11:1-22.

Ayres-Bennett, Wendy (1994). Negative evidence: Or another look at the non-use of ne in 17thcentury French. French Studies 48:63-85.

(2000). Voices from the past: Sources of seventeenth-century spoken French. Romansiche Forschungen 112:323-48.

(2004). Sociolinguistic variation in seventeenth-century France: Methodology and case studies. Cambridge: Cambridge University Press.

Backus, Ad (2005). Code-switching and language change: One thing leads to another? International Journal of Bilingualism 9(3/4):307-40. 
Bailey, Guy (2002). Real and apparent time. In Jack K. Chambers et al. (eds.), The handbook of language variation and change, 312-32. Malden, MA: Blackwell.

; Wikle, Tom; Tillery, Jan; \& Sand, Lori (1991). The apparent-time construct. Language Variation and Change 3(1):241-64.

Baugh, John (1996). Dimensions of a theory of econolinguistics. In Gregory Guy et al. (eds.), Towards a social science of language: Papers in honor of William Labov, vol. I, 397-419. Amsterdam: John Benjamins.

Bell, Allan (1984). Language style as audience design. Language in Society 13:145-204.

Blondeau, Hélène (2002). Retracer la voie du changement en temps réel en français québécois. Paper presented at Canadian Linguistic Association 2002 meeting. Toronto, Canada. (2003). The old nous and the new nous: A comparison of 19th and 20th century spoken Quebec French. University of Pennsylvania Working Papers in Linguistics 9(2):1-15. (2004). Variation pronominale et changement d'usage en français québécois du XIXe et XXe siècles. Paper presented at DIACHRO-II: Phénomènes de changement en français, Paris.

Blanche-Benveniste, Claire, \& Jeanjean, Colette (1986). Le français parlé: Transcription et édition. Paris: Didier.

Carruthers, Janice (2003). Tense, orality and narration: The case of the néo-conte. French Studies 57(4):501-20.

Chambers, Jack K., \& Trudgill, Peter (1980). Dialectology. Cambridge: Cambridge University Press.

Coveney, Aidan (1996). Variability in spoken French. Exeter: Elm Bank.

Corbeil, Jean-Claude (1976). Origine historique de la situation linguistique québécoise. Langue française 31:6-19.

Cukor-Avila, Patricia (2000). The stability of individual vernaculars. Ms., University of North Texas.

Daveluy, Michelle (1987). L'usage des déterminants démonstratifs dans la communauté francophone de Montréal en 1971 et 1984. MA thesis, Université de Montréal.

Dion, Nathalie (2003). L'effacement du que en français canadien: Une étude en temps réel. MA mémoire, University of Ottawa.

(2006). Que fait que: Evolution des complétives dans le français d'ici. Paper presented at Les français d'ici: Acadie, Québec, Ontario, Ouest canadian, Queen's University, Kingston, Canada. , \& Torres-Cacoullos, Rena (2003). À la recherche du que perdu: Une étude en temps réel.

Paper presented at Canadian Linguistic Association 2003 meeting, Halifax, Canada.

Drapeau-Forzani, Denyse (1977). Contribution à l'étude lexicale de contes québécois du début XXe siècle: Étude des mouvements, des pensées et des sentiments de l'homme. MA mémoire, Université Laval.

Dufter, Andreas, \& Stark, Elisabeth (2005). Variable ne omission in French negation: Reconstructing change in spoken varieties. Paper presented at the Third International Conference on Language Variation in Europe, Amsterdam, Meertens Instituut.

Elsig, Martin, \& Poplack, Shana (2006). Transplanted dialects and language change: Question formation in Québec. University of Pennsylvania Working Papers in Linguistics 12.2: Selected Papers from NWAVE 34, 77-90.

Gordon, Elizabeth; Campbell, Lyle; Hay, Jennifer; Maclagan, Margaret; Sudbury, Andrea; \& Trudgill, Peter (2004). New Zealand English: Its origins and evolution. Cambridge: Cambridge University Press.

Grevisse, Maurice (1986). Le bon usage: Grammaire française. Paris: J. Duclot.

Juneau, Marcel (1976). La jument qui crotte de l'argent: Conte populaire recueilli aux GrandesBergeronnes (Québec). Édition et étude linguistique. Québec: Presses de l'Université Laval.

Klapka, Lyne (2002). Étude comparative: L'Accord du genre en français québécois au XIXième et au XXième siècles. MA mémoire, University of Ottawa.

Labov, William (1966). The social stratification of English in New York City. Washington, DC: Center for Applied Linguistics.

(1984). Field methods of the project on linguistic change and variation. In John Baugh \& Joel Sherzer (eds.), Language in use: Readings in sociolinguistics, 28-54. Englewood Cliffs, NJ: Prentice-Hall.

(1994). Principles of linguistic change. Volume 1: Internal factors. Oxford: Blackwell. , \& Auger, Julie (1998). The effect of normal aging on discourse: A sociolinguistic approach. In Hiram H. Brownell \& Yves Joannet (eds.), Narrative discourse in neurologically impaired and normal aging adults, 115-34. San Diego, CA: Singular. 
Lacourcière, Luc (1946). La Langue et le folklore. Canada français (Québec) 33(7):489-500. (1959). Contes et légendes. In Le Congrès de la Refrancisation, Québec, 21-24 juin 1957. Québec, Éd. Ferland, 6:25-35.

(1961). Le Conte populaire français en Amérique du Nord. In Internationaler Kongress der Volkserzanlungsforscher, 142-51. Berlin: de Gruyter.

(1962). L’Étude de la culture: Le Folklore. In Situation de la recherche sur le Canada français, 253-62. Québec: Presses de l'Université Laval.

(1966). La Tradition orale au Canada. France et Canada français du XVIe au XXe siècle (colloque d'histoire). Québec: Presses de l'Université Laval (Cahiers de l'Institut D'Histoire 7:223-31 and 232-43).

, \& Savard, Félix-Antoine (1950). Canadian folktales recorded during the summer of 1948 in Charlevoix and Beauce Counties. Bulletin of the National Museum of Canada, Department of Mines 118:63-65.

(1951). Canadian folk songs, collected at Baie-des-Rochers (Charlevoix). In Annual Report of the National Museum of Canada for the Fiscal Year 1949-1950, 84-87. Ottawa: Minister of Resources and Development (Bulletin 123).

(1953). Mots et choses d'Acadie. In Annual Report of the National Museum of Canada for the Fiscal Year 1951-1952, 98-102. Ottawa: Minister of Resources and Development (Bulletin 128).

La Follette, James E. (1969). Étude linguistique de quatre contes folkloriques du Canada français: Morphologie et syntaxe. Québec: Presses de l'Université Laval (Archives de Folklore 9).

LeBlanc, Carmen (1999). Du conditionnel dans les propositions hypothetiques en si: Cet intrus. MA thesis, University of Ottawa.

(2002). The conditioning of the French conditional redux: A real-time analysis. Paper presented at NWAVE 31, Palo Alto, California.

, \& Poplack, Shana (1999). Conditions on the conditional. Paper presented at Linguistic Symposium on Romance Languages, Ann Arbor, Michigan.

(2003). Les si chassent les -rais ?: une étude du conditionnel en temps réel. Paper presented at the Canadian Linguistic Association 2003 Meeting, Halifax, Canada.

Leroux, Martine (2004). Relics of the Canadian French past. Paper presented at NWAVE 33, Ann Arbor, Michigan.

, \& Jarmasz, Lidia-Gabriela (2006). A study about nothing: Null subjects as a diagnostic of convergence between English and French. University of Pennsylvania Working Papers in Linguistics 12.2: Selected papers from NWAVE 34, 1-14.

Lessard, Pierre (1989). Variabilité linguistique et variabilité sociale dans la communauté francophone de Montréal. MA thesis, Université de Montréal.

Lightfoot, David (1999). The development of language: Acquisition, change and evolution. Malden, MA: Blackwell.

Lodge, Anthony (1996). Stereotypes of vernacular pronunciation in seventeenth- and eighteenthcentury Paris. Zeitschrift für Romanische Philologie 112:205-31.

(2003). Reallocation between standard and vernacular in early modern Paris. Sociolinguistica 17:88-107.

Martineau, France, \& Mougeon, Raymond (2003). A sociolinguistic study of the origins of ne deletion in European and Quebec French. Language 79:118-52.

Moreau, Marie-Louise (1986). Les séquences préformées: Entre les combinaisons libres et les idiomatismes. Le cas de la négation avec ou sans ne. Le Français Moderne 54:137-60.

Mougeon, Raymond, \& Béniak, Édouard (eds.) (1994). Les origines du français québécois. SainteFoy: Presses de 1'Université Laval.

Pohl, Jacques (1968). Ne dans le français parlé contemporain: Les modalités de son abandon. Actes du XIe Congrès International de Linguistique et Philologie Romanes, Madrid, 3:1343-59.

(1975). L'omission de ne dans le français contemporain. Le Français dans le Monde 14: 17-23.

Poirier, Claude (1973). La Langue de Paul Vachon, notaire québécois du dix-septième siècle. Étude phonétique. MA mémoire, Université Laval.

(ed.) (1998). Dictionnaire historique du français québécois: Monographies lexicographiques de québécismes. Sainte-Foy: Presses de l'Université Laval.

Pomerleau, Jeanne (1997). Bûcherons, raftmen et draveurs: 1850-1960. Sainte-Foy: J.-C. Dupont. 
Poplack, Shana (1989). The care and handling of a mega-corpus. In Ralph Fasold \& Deborah Schiffrin (eds.), Language change and variation, 411-451. Amsterdam: Benjamins.

(1992). The inherent variability of the French subjunctive. In Christiane Laeufer \& Terrell Morgan (eds.), Theoretical analyses in Romance linguistics, 235-63. Amsterdam: Benjamins. (1993). Variation theory and language contact. In Dennis Preston (ed.), American dialect research: An anthology celebrating the 100th anniversary of the American Dialect Society, 25186. Amsterdam: Benjamins.

(1997). The sociolinguistic dynamics of apparent convergence. In Gregory Guy, John Baugh \& Deborah Schiffrin (eds.), Towards a social science of language, 285-309. Amsterdam: Benjamins. (2000). Variation, prescription and praxis: Stages of prescriptive grief. Paper presented at the Sociolinguistics Symposium, Bristol, UK.

; Jarmasz, Lidia-Gabriela; Dion, Nathalie; \& Rosen, Nicole (in preparation). The evolution of French prescriptive discourse: Constructing the Répertoire historique des grammaires $d u$ français. Ms., University of Ottawa.

, \& Dion, Nathalie (2004). The French future in grammar, thought and speech. Paper presented at NWAVE 33, Ann Arbor, Michigan.

, \& Malvar, Elisabete (2007). Elucidating the transition period in linguistic change. Probus 19(1):121-69.

, \& Meechan, Marjory (1998). How languages fit together in code-mixing. International Journal of Bilingualism 2(2):127-38.

\& St-Amand, Anne (2002). Advienne que pourra: Retour sur le subjonctif français. Paper presented at the Canadian Linguistic Association 2002 Meeting, Toronto, Canada.

(forthcoming). Les Récits du français québécois d'autrefois: Reflet du parler vernaculaire du XIXe siècle.

, \& Tagliamonte, Sali (1991). African American English in the diaspora: Evidence from oldline Nova Scotians. Language Variation and Change 3:301-39. (2001). African American English in the diaspora. Oxford: Blackwell.

, \& Turpin, Danielle (1999). Does the FUTUR have a future in (Canadian) French? Probus 11(1):133-64.

; Walker, James; \& Malcolmson, Rebecca (2006). An English "like no other"?: Language contact and change in Quebec. Canadian Journal of Linguistics 51(2):185-213.

Posner, Rebecca (1985). Post-verbal negation in nonstandard French: A historical and comparative view. Romance Philology 39:170-97.

Roy, Carmen (1958). Enquête de Mme Roy: Transcriptions des bandes sonores (1958). Musée Canadien des Civilisations, Bibliothèque, Archives et Documentation. Dossier Roy-A-131, boîte 473 f. 5. (1981). Littérature orale en Gaspésie. 2nd ed. Ottawa: Léméac.

Sankoff, David (1988a). Sociolinguistics and syntactic variation. In Frederick J. Newmeyer (ed.), Linguistics: The Cambridge survey, 4:140-61. Cambridge: Cambridge University Press.

(1988b). Variable rules. In Ulrich Ammon, Norbert Dittmar \& Klaus J. Mattheier (eds.), Sociolinguistics: An international handbook of the science of language and society, 984-97. Berlin: Walter de Gruyter.

Sankoff, Gillian (2005). Cross-sectional and longitudinal studies in sociolinguistics. In Ulrich Ammon, Norbert Dittmar, Klaus J. Mattheier \& Peter Trudgill (eds.), Sociolinguistics: An international handbook of the science of language and society, 2:1003-13. Berlin: Walter de Gruyter.

; Evans Wagner, Suzanne; Thibault, Pierrette; \& Blondeau, Hélène (2006). Changement linguistique ou changement des locuteurs? Deux problèmes de morphologie verbale à travers le temps. Paper presented at Colloque International sur les Variétés de Français au Canada, Kingston, Canada. \& Vincent, Diane (1977). L'emploi productif du ne dans le français parlé à Montréal. Le Français Moderne 45:243-54.

(1980). The productive use of ne in spoken Montréal French. In Gillian Sankoff (ed.), The social life of language, 295-310. Philadelphia: University of Pennsylvania Press.

St-Amand, Anne (2002). Le subjontif suivant une expression non-verbale. MA mémoire, University of Ottawa.

Thomason, Sarah Grey (2001). Language contact. Edinburgh: Edinburgh University Press.

Van Herk, Gerard (1999). "Ain't-shaped holes” and Standard English that isn't: Negation and literacy in Early African American English letters. Paper presented at Methods X meeting. St. John's, Canada. 
\& Poplack, Shana (2003). Rewriting the past: Bare verbs in the Ottawa Repository of Early African American Correspondence. Journal of Pidgin and Creole Languages 18(2):231-66.

Willis, Lauren (2000). Etre ou ne plus être: Auxiliary alternation in Ottawa-Hull French. MA thesis, University of Ottawa.

Wüest, Jakob (2002). Marques d'oralité et conventions littéraires dans les anciens textes en français populaire. In Rodney Sampson \& Wendy Ayres-Bennett (eds.), Interpreting the history of French: A Festschrift for Peter Rickard on the occasion of his eightieth birthday. Amsterdam \& New York: Rodopi.

(Received 26 September 2005; revision received 24 July 2006; accepted 1 August 2006; final revision received 3 August 2006) 